\title{
Ars Vitae and Sport
}

\section{Authors' contribution:}

A) conception and design of the study

B) acquisition of data

C) analysis and interpretation of data

D) manuscript preparation

E) obtaining funding

\section{Miloš Bednář}

Charles University in Prague, Czech Republic

\section{ABSTRACT}

Our study aims to contribute to the approach of leading an optimal life and especially to the role of sport and physical activities in this life.

First, we have tried to find the optimal personal qualities which may be proper for the ars vitae (the art of life). Five of them (creativity, calculation, cooperation, concentration, and credibility) were chosen (on the empirical bases of long-time ethical seminars with students studying physical education) and annotated. This was done taking into account the practical applicability in sport.

Further, we have focused on proper biodromal projects, which are based on some traditional models. We judge sport can significantly contribute to the study three of these; at the same time, they are very useful in the sphere of sport. Thus the opposites of the Dionysian and Apollonian tendency of life, and the authentic and inauthentic one, were chosen for closer analysis. The third proper model (hedonism versus asceticism) was examined in an earlier study. More attention has been paid to antagonistic and integrative models of authenticity, and our conclusion was that we ought to consider them in mixed form when periods of antagonistic authenticity are replaced with periods of integrative authenticity in real life. Concrete examples have been taken from the field of sport. Kretchmar's structural model of the good life is connected with this field more firmly and has been critically examined in the last chapter.

In conclusion, we name four conditions for the creation of optimal biodromal projects and for forming the real ars vitae.

KEYWORDS ars vitae, authenticity, biodromal projects, personal qualities

\section{Introduction}

"I find myself in an immeasurably vast world of sensible and spiritual objects which set my heart and passions in constant motion," said Max Scheler in his "Ordo Amoris" (1992, p. 98). Of course, the endless world of material objects also had an influence on us. Yet we receive movement not only outwardly, but we are the source of much movement as well: our hearts are permanently running pumps, our minds produce hundreds of thoughts, etc. We can say with old-fashioned style: panta (in our life) rhei. Or, with postmodern style: life is a multilevel of movements. But we would like to look at human life as a whole, to consider its horizons, and to follow the very special movements of human existence. How does one "run" throughout the course of life and not fail? How do we lead our lives (vitam ducere) in an optimal way? Achieving this goal is the real ars vitae - the art of life. 
It is obvious that successful ars vitae requires (minimally):

1. Developing optimal personal qualities.

2. The ability to choose optimal biodromal projects.

\section{Developing optimal personal qualities and the role of sports activities in this}

Using the term personal quality, we would like to combine virtues, skills, and knowledge into one term. Its crux ought to lie in virtues. The next choice was done on the basis of 12 year of seminar work in ethics with university students studying physical education (about 200 of them each year), in which they identified the most important personal qualities from the field of sport.

\section{Creativity}

We can divide creativity into two types: day-to-day, and specific. This means a way to find and lead an optimal life in one's context or how to face troublesome situations with invention. This can give very significant additional value to athletes' skills, especially in ball (team) games, and differentiates players with the same level of technical skills or the same level of training (only one example from football: Lionel Messi). Other sports arenas need more creativity: sports disciplines joined with art, such as figure skating, dancing, etc. Yet we would say additionally that any sport provides a chance for creativity from inventors of new styles or techniques. A good example here is Richard Fosbury with his flop.

\section{Calculation}

We do not only mean the aspect of counting, but an orientation towards the future; the anticipation of coming action. An artist ought to "see" (calculate!) the final artifact first - an "artist of life" no less. Athletes have good training in many types of calculation - they must be purposeful, they ought to anticipate the actions of rivals; each match or event is full of calculations of different types (concerning the score, the remaining time, etc.). Both aspects of calculation are present in so-called brain games, like chess: one must calculate their future steps anticipating those of a rival. A problematic area can be connecting the calculation of optimal biodromal projects in the perspective of a whole life. How does one combine sports, family, and a career in life? How to live after the end of an elite sports career?

\section{Cooperation}

The ability to cooperate is a basic condition for sound interpersonal relations and a necessary part of human development. Cooperation itself is living both in human performances and in a crystallized form in relation to things around one's self. Natural egocentrism and egoism ought to be overcome in educational systems, beginning in families. Effective cooperation is joined with another skill - empathy.

Sports organizations can play an important role in this orientation towards cooperation. There is a wide range of tasks here: from effective influence on young athletes to forming a special task force for team building in the field of elite sport. Each member of the team must have this personal quality. This is conditio sine qua non for building so-called team spirit, which opens the door to success. A player with a higher level of this quality ("team player") has an important position in the team hierarchy ("team brain") especially in football (e.g., Xavi Hernandez), basketball (e.g., Steve Nash), ice hockey (e.g., Jaromír Jágr), and other team games. Maybe even more visible is the role of cooperation on small teams such as (table) tennis, badminton, or doubles beach volleyball. It is not rare for two average players to form a top team (e.g. Robert and Michael Bryans in tennis). 


\section{Concentration}

In the current age, we do not like narrow specialization. Concentration on one topic over the course of life is not apt. We plead for flexible controlling of the focus of attention. It can be wide-ranging: from concentration on simple daily activities to mental concentration like samadhi. Sometimes we need concentration on one matter in one moment with deeper "immersion". Deep concentration is also present in the lived experience of the type peak, zone, or flow experience (we compared them in Bednář, 2011).

The ability to concentrate is an essential component of the majority of sports events, especially in shooting and archery. The absence of concentration can dash an athlete's chances of success even after longterm training - especially in sports where final performances are a question of one second or less (e.g., jumps of any type in athletics).

Old eastern techniques such as the yoga technique tratak (working with a flame of candle or lamp) and especially meditation are also used to improve concentration in the field of sport. Meditation is considered to be the most powerful of all concentration enhancement techniques. The simplest and most direct method for developing concentration skills is to focus on one's own breath. Sport psychologists have discovered some new techniques for workong with breathing, which is close to most athletes.

We judge that an important role here is also played in the struggle with distractions of the "world," where athletes are attacked on the side of business, media, fans, etc. Finding concentration here can be a hard task, especially following a high achievement.

The whole sports life can be understood as a rotation of concentration and relaxation from a wider point of view.

\section{Credibility}

Finis coronat opus: we can speak of "over-virtue", concentrating all the other qualities in one. Credibility has two key components: trustworthiness and expertise. Secondary components of credibility include charisma and attractiveness. "Credit is money" (Franklin), but to have credit, to be credible, is more: credibility opens the door and is the cornerstone of our integrity.

Sport is a proper area where one can demonstrate credibility. This human quality is here closely joined with fair play. Gaining credibility is a question of many years; losing it can be a question of one moment, one bad decision, one unfair act. Unfortunately, there are many examples in recent years. Only three names come from the top of elite sports: Marion Jones, Tiger Woods, and Lance Armstrong. By the way, the ambiguity (both in the ethical and financial sense) of the word credit is ironically showed here. We must not forget that these cases also have an influence on the credibility of the whole sports event (for example, the loss of the trustworthiness of cycling during recent years).

We would like to add that the following positions were placed with contemplation, communication, authenticity, criticism, and competency.

\section{The ability to choose optimal biodromal projects}

Although each project is very individual, we can follow some models or be inspired by them. Here are some traditional examples:

1. Bios apolaustikos - bios politikos - bios theoretikos (Aristotle);

2. Vita vitiosa - vita activa - vita contemplativa (Christianity);

3. Hedonism versus asceticism (Epicurus, Stoics et al.);

4. Dionysian versus Apollonian mode of life (Nietzsche);

5. Authenticity versus inauthenticity (Heidegger, Taylor et al.);

6. Camel - lion - child (Nietzsche);

7. Aesthetic - ethical - religious levels of life (Kierkegaard). 
We judge that sport can contribute to the study three of them $(3,4$, and 5) significantly - additionally, they can be very useful for the sphere of sport itself.

We would like to analyze and interpret two of them (4 and 5); another (3) has previously been examined (Bednáŕ, 2009).

\section{Optimal biodromal projects and sport}

\section{Dionysian versus Apollonian tendency of life (Nietzsche)}

Nietzsche created this model on the basis of Greek tragedy (in his Die Geburt der Tragödie from 1872). He came to the conclusion that the fusion of Dionysian and Apollonian artistic impulses forms tragedies. The "official" role of both gods is well known; what they symbolize is more important for our topic. We have tried to compare both modes in table 1 .

Table 1. Comparison of the Dionysian and Apollonian tendency of life

\begin{tabular}{llllll}
\hline & $\begin{array}{l}\text { Impact of } \\
\text { lifestyle }\end{array}$ & $\begin{array}{l}\text { Luminary } \\
\text { imaginativeness }\end{array}$ & $\begin{array}{l}\text { Social } \\
\text { dimension }\end{array}$ & $\begin{array}{l}\text { Relation to } \\
\text { reality }\end{array}$ & $\begin{array}{l}\text { Fundamental } \\
\text { area }\end{array}$ \\
\hline Dionysian & intoxication & darkness & community & "hard" reality & fysis/earth \\
Apollonian & dream/sleep & light/ glare & individuality & illusion/ image & heaven \\
\hline
\end{tabular}

Source: (Nietzsche, 1872).

Though the dichotomy of both is evident, the border between them is not firmly closed. Incidentally, Nietzsche speaks of "fusion". We judge that the fusion is also necessary when we move both modes into the structure of human existence. The (moveable) border lies inside us in this case. The art of life consists of mild harmonisation: sometimes we revive our Dionysian nature drawing from this deep source and so touching what Nietzsche calls the "Primordial Unity", and at other times we dream our Apollonian dreams of "flying in the heaven". It is noted here that Apollo and Dionysus were brothers in Greek mythology. We can speak of the dialectic relation between both modes in less poetic language.

There are some attempts to apply Nietzsche's paradigm to other areas of human activity (e.g., Romain Rolland for composers) not yet in the field of sport.

Of course, there are examples of "Apollo" among athletes. They do reasonable things and their training is controlled by the use of scientific methods. They are also ready to respect and to adopt some objective order of values or social ideals, and to promote their distribution among (not only) other athletes. They are a paragon of virtue for youth.

And, of course, there are also examples of "Dionysus" among athletes. Their training is often rather chaotic and their decisions unexpected. They often rely on their own feelings and intuition more than on recommendations from others. They are really connected to the ground: skiers have a perfect feeling for snow, water sportsmen for water, etc. They usually prefer outdoor activities. Their regime is not exemplary, though in spite of it they achieve success. They have certain trouble respecting social norms and prefer to follow their own ranking of values. Maybe they are not paragons for youth, yet the youth love them.

We judge that a bridge of some sort between both types could be the human heart (i.e., spiritual heart) with its special "order of love". Max Scheler termed it Ordo Amoris, following Blaise Pascal (see Scheler, 1992). The heart has a logic of its own that is quite different from the logic of reason. This could be understood as a sort of "sixth sense". Both modern Apollos and Dionysos can draw from this source. Yet it is necessary to remember that the heart/love also has a darker side. Erich Fromm analyzed this aspect from a psychological point of view in his The Heart of Man (1964). His position is better explained by the subtitle of this book: Its Genius for Good and Evil. We can also speak of the shadow inside us, according to Carl Gustav Jung. 


\section{Authenticity versus inauthenticity}

The question of authenticity is one of the most important contemporary topics, though the origin of its study is connected with the philosophers Kierkegaard, Nietzsche, Sartre, and Camus. Authenticity has been in the center of attention from the time of Heidegger's analysis in Sein und Zeit (1927). Heidegger mentioned three main features of authenticity: affectedness/state-of-mind (Befindlichkeit), understanding (Vestehen), and discourse/telling (Rede) ( $\$ 29$ up to $\S 37$ ). Heidegger's other analyses of authenticity concerning fear, anxiety, death, and conscience are also inspiring. Many authors have also found them useful for the area of sports. We can name Satoschi Higuchi (1991), Anna Hogenová (2006), Ivo Jirásek (2007), Emanuel Hurych (2009), Arno Müller (2011), and (especially) Gunnar Breivik (2010). The latter appeals: "It is time to bring authenticity more into focus also in philosophy of sport discussions" (Breivik, 2010, p. 30).

Yet the engagement of sport in today's discourse from an ethical standpoint of authenticity seems to be more pragmatic and useful for the field of sport. The main authors here are Charles Taylor (1992) and Alessandro Ferrara $(1994,1998)$. They use the term "authenticity" for the contemporary moral ideal.

Ferrara's analysis of two opposite streams of historic reflections concerning authentic subjectivity (see Ferrara, 1998, pp. 53-60) and one example of the contrasting models of authenticity, antagonistic and integrative, seem the most useful for our intention in sport. Though Ferrara considered these two models as opposites - incorporated in opposite human types - we are instead persuaded that the border is usually placed inside human beings and that "pure" types are very rare in concrete lives.

In this way, we promote such a model when periods of antagonistic authenticity (often in the form of rebellion against ruling norms, or as exceptional experiences) are replaced with periods of integrative authenticity (a time of synthesis and forming a new identity).We think it really exists in our life-course and it is necessary for flexible and meaningful life projects.

This model is well represented in the field of sport even with its embodied polarity.

There are a lot of examples in the history of sport where athletes fulfilled Taylor's requirement of "being true to their own originality" and went against the tide. There are also athletes with integrative potential, forming optimal sports values, shared above all in the Olympic or Fair Play movements. They form a raison d'être for sport as a whole as well.

\section{Kretchmar's structural model of the good life}

What features should the model of the good life, which can offer kinesiology/kinanthropology for sport-oriented/physically active people, posses? Scott Kretchmar, who is persuaded that striving after authenticity is helpful for leading an optimal life, presents one answer. The good life ought to embrace the strenuous, sensuous, spiritual, and excellent lifestyle (see Kretchmar 2005, pp. 246-252) wherein "activityoriented people live all four profiles in various intensities and combinations" (ibid., p. 246). Kretchmar has patterned after William James a definition of the good life: "The good life came from engaging the world, from struggling for improvement in an open existence whose future is uncertain" (ibid.). Kretchmar thinks sport and exercise can be comparable to this view of James because it requires virtues such as "strong will, courage, a willingness to suffer, and a commitment to progress" (ibid., p. 248). We can agree from a theoretical point of view, but based on today's sport reality we are a bit more vigilant. The stated virtues ought to be in at the optimal "value", far from all extremes - as was Aristotle's intention. The body can be weaker than a strong will, inadequate courage can lead to disaster, repeated suffering to the loss of sensitivity, and a commitment to progress must sooner or later run into problems, as progress is not endless.

There is no discussion that "the good life includes significant experiences of aesthetic delight in movement, nature, art, music, and other parts of the sensory world" (ibid., p. 250). The aesthetic dimension has been a strong part of "sports" (movement culture!) from ancient times, and it is "hidden" in KALOkagathia as well. Beauty is part of special types of sport in our times (figure skating, aerobics, etc.). There can be trouble in this regard with participation of the other parts of the sensory world, notably during 
hard training. Hours and hours in the swimming pool, or many other indoor activities, are far from sensoryrich lives. On the opposite side, a sensory-rich environment obviously forms one aspect of the rising popularity of outdoor activities.

Increasing attention is paid to the spiritual dimension of physical activities as well. If attention to the body was at the center of sports science at the beginning, attention to the psychology of sport arrived minimally at the foundation of the International Society of Sport Psychology (1965) (though isolated studies were published between the world wars). The worldwide initiative "Sport and spirituality" was only then established in 2007 as a follow-up to a conference of the same name at St. John University in York (though some books and studies were published about this topic earlier, especially in the United States). Conference contributions became the foundation of a monograph published in 2011 under the title Theology, Ethics and Transcendence in Sports.

There is no secret that some new ways to improve performances are being sought here. It is known also in the field of spirituality that "Movement has played a major role in promoting spiritual experiences" (ibid., p. 250). Kretchmar presents monks (from the Order of Saint Benedict) as an example of those who knew how to connect physicality and spirituality, and thus names them "spiritual athletes" (! - see ibid.).

Yet key word here is spiritual experience. Kretchmar quotes examples from long-distance running (Kostrubala) and archery (Herrigel - Eastern approach). We should like to add mountaineering with its "touching the void" (hint from the famous book by Simpson with the same name, 1988) and remind the reader of the work concerning peak experiences in the field of sport (maybe the first was Ravizza, 1977; see more in Bednár, 2011). Abraham Maslow, the father of the term, found these types of experiences in the area of religious experiences first, but he later secularized them: "The term 'peak experience" is the generalization of the best moments of a human being, the happiest moments of life, experiences of ecstasy, enthusiasm, blessedness or the greatest joy" (Maslow, 1971, p. 105).

The final feature of the good life focuses on excellence. Kretchmar promoted balanced excellence, connecting knowledge and skills. It is almost the same point we reached at the beginning of this article: our "mixture" has added virtues and we elaborate this concept into the "5 C's".

It is important that Kretchmar connects this lifestyle with freedom: "the excellent life ... provides increasing degrees of freedom - more choices, less fear, more creativity, less ignorance" (Kretchmar, 2005, p. 252). This dimension might be worthy of a separate dimension as the fifth lifestyle/profile.

Going back to excellence, it is good to remember the old Greek term arête, which is usually translated as virtue, but precisely excellence is closer to the original meaning, i.e., to show the best of my personality, not only in a moral sphere. This term played a great role in Greek thinking and was also one of the key words of ancient Olympism. Recently, Holowchak and Reid (2011) tried to revive arete with the book Aretism: An Ancient Sports Philosophy for the Modern World.

\section{Discussion}

We have discussed concrete topics continuously. Yet there are many other questions opened:

1. We have paid more attention to five personal qualities and we named five others. Yet we are sure that the list could be longer - in addition to those named, preparation for spirituality/transcendence, for catharsis or for suffering, for example. What else?

2. We plead for wider focus on the ordo amoris in the field of sport. Yet, can we find proper methods for studying this special "order of love" (with its own "logic")?

3. In relation to authentic experiences, we have another question to answer: Do they happen when I am fully "absorbed" in an activity (and thus "outside of myself"), or when I am able to see myself as a part of the whole, with "all" contexts, horizons, and the like? 


\section{Conclusion}

Our study strives to contribute to a kinanthropological approach to leading an optimal life and especially to the role of sport and physical activities in this life.

First, we have tried to identify optimal personal qualities. Our approach is philosophical and it is close to that of an existentialist, yet we feel it will be necessary to cooperate more with psychology and sociology in future research of this interdisciplinary topic.

Further, we focused on the contrast between the Dionysian and Apollonian tendencies of life and concrete examples were taken from the field of sport.

We judge that wider attention ought to be paid to the "spiritual heart" with its "order of love" in the field of sport because sport is not an area of "pure reason". Instead, it has its own "sixth sense," irrational features, and an ocean of emotions.

We propose a balanced model of authenticity respecting and synthesizing both the integrative and antagonistic moments of our lives. The area of sports provides many examples from both poles of authenticity and can be a good educational tool for maturation and development.

Heidegger's accurate analyses of authenticity (and also inauthenticity) can find a specific place in these reflections as well.

Further analyses also ought to be focused on the question of asceticism - sport can make an important contribution to this topic in our hedonistic postmodern age. We could see ascetic features in Kretchmar's model, especially with its strenuous and spiritual dimensions.

We would summarize that the creation of optimal biodromal projects requires:

- being a good "project manager of oneself",

- consider the optimal "speed" and "timing" of one's own life with a long-term perspective, taking in account the limitations of human finality,

- strive for proper values, incarnating them into the structure of one's own existence,

- create (do not just search!) one's own meaning of life, which is connected to one's aim and mission in life.

To find a personal authentic model of life is the real ars vitae.

\section{Acknowledgement}

This study was supported by the Research Grant PRVOUK P39 /Czech Republic/.

\section{REFERENCES}

Aristotle. (2009). The Nicomachean Ethics. Oxford: Oxford University Press.

Bednár, M. (2009). Sport, Asceticism and Hedonism. Journal of Outdoor Activities 2, 4-11.

Bednár̆, M. (2011). Experiental Gateway into Spiritual Dimension in Sport. Acta Facultatis Educationis Physicae Universitatis Comenianae, 51, 75-84.

Blattner, W. (2006). Heidegger's Being and Time: A reader's guide. London \& New York: Continuum Books.

Breivik, G. (2010). Being-in-the-void: A Heideggerian analysis of skydiving. Journal of the Philosophy of Sport 37, 2946.

Ferrara, A. (1994). Authenticity and the Project of Modernity. European Journal of Philosophy, 2, 241-273.

Ferrara, A. (1998). Reflective Authenticity: Rethinking the Project of Modernity. London and New York: Routledge.

Fromm, E. (1964). The Heart of Man: Its Genius for Good and Evil. New York: Harper \& Row.

Heidegger, M. (1977). Sein und Zeit. Frankfurt am Main: V. Klostermann.

Heidegger, M. (1962). Being and Time. New York: Harper \& Row. 
Higuchi, S. (1991). Heidegger's concept of authenticity and sport experience. Bulletin of the Faculty of Education, Hiroshima University 39, 131-137.

Hogenová, A. (2006). Movement and time. Acta Universitatis Palackianae Olomucensi,s 36, 47-52.

Holowchak, M.A., Reid, H.L. (2011). Aretism: An ancient sports philosophy for the modern world. Lanham: Lexington Books.

Hurych, E. (2009). Martin Heidegger and some ontological and phenomenological aspects of outdoor activities sport. Journal of Outdoor Activities, 2, 12-29.

Jirásek, I. (2007). An experience and Heidegger's analysis of authentic existence. In H. Sheridan, L.A. Howe, \& K. Thompson (Eds.), Sporting reflections: Some philosophical perspectives (pp. 154-170). Oxford: Meyer \& Meyer Sport.

Kretchmar, R.S. (2005). Practical Philosophy of Sport and Physical Activity. Champaign, IL: Human Kinetics.

Maslow, A. (1971). The Farther Reaches of Human Nature. New York: Viking Press.

Müller, A. (2011). From phenomenology to existentialism: Philosophical approaches towards sport. Sport, Ethics and Philosophy 5, 202-216.

Nietzsche, F. (2008). The Birth of Tragedy. Oxford: Oxford University Press.

Parry, J., Nesti, M. and Watson, N. (Eds). (2011). Theology, Ethics and Transcendence in Sports. New York: Routledge.

Ravizza, K. (1977). Peak Experiences in Sport. Journal of Humanistic Psychology, 17, 35-40.

Scheler, M. (1992). Ordo Amoris. In Selected philosophical essays (pp. 98-135). Evanston: Northwestern University Press.

Simpson, J. (1988). Touching the Void. London: Vintage.

Taylor, C. (1992). The ethics of authenticity. Cambridge (Mass.) and London: Harvard University Press.

AUTHOR'S ADDRESS: $\quad$ Miloš Bednář

Faculty of Physical Education and Sport

Charles University in Prague

José Martího 31

16252 Praha 6, Czech Republic

E-mail: milbed@volny.cz 